\title{
Hospitalization of injured immigrants in Poland - Utilization of in-patient services
}

\author{
Dorota Cianciara', Paweł Goryński', Wojciech Seroka² \\ ${ }^{1}$ Department of Epidemiology and Health Promotion, School of Public Health, Centre of Postgraduate Medical \\ Education, Warsaw, Poland \\ ${ }^{2}$ Department - Centre for Monitoring and Analysis of Population Health Status and Health Care System, National \\ Institute of Public Health - National Institute of Hygiene, Warsaw, Poland
}

Cianciara D, Goryński P, Seroka W. Hospitalization of injured immigrants in Poland - Utilization of in-patient services. Ann Agric Environ Med. 2016; 23(3): 472-475. doi: 10.5604/12321966.1219190

\begin{abstract}
Introduction and objective. In 2008-2010, the number of foreigners hospitalized due to injuries in Poland ranged from approximately 5-21 thousand. The aim of this study was to analyse the utilization of in-patient services by injured immigrants in 2008-2010, including mode of admission (i.e. referral), mode of discharge, average length of patient stay, seasonality and spatial distribution of hospital admissions.

Material and methods. Analysis was conducted on the basis of data from the General Hospital Morbidity Study. All cases of hospitalization due to injuries were covered by the analysis, and a group of foreigners was compared to the general population.

Results. The percentage of immigrants admitted by acute admission through self-referral increased to $80.9 \%$ in 2010 . The great majority (79.4\%) were discharged to in-patient care. The immigrants' stay in the hospital was approximately twice as short than that of an average patient with injury. Immigrants and the rest of the patients were admitted to hospitals in different seasonal rhythm. The great majority of foreigners were treated in hospitals located in two (out of 16) provinces. Conclusions. This study supports the need for understanding the immigrant experience when accessing health care, as well as the need for further research and contribution of public health.
\end{abstract}

\section{Key words}

Immigrants, hospitalization, injuries, geographical distribution, Poland

\section{INTRODUCTION}

The literature indicates that most commonly the risk of occupational injury for foreign-born workers is higher than that of native workers [1]. Such a relationship was also observed in the group of documented immigrants [2]. Information about the risk of traffic injuries of immigrants is scarce and provides conflicting data $[3,4]$. Other kinds of injuries, e.g. injuries around the house may also pose a great burden [5].

Data on the utilization of health services by immigrants vary by country and type of data [6]. The great diversity of utilization of health services refers to the level of care; however, a higher utilization of emergency care is commonly observed $[6,7,8]$. Data on hospitalization are conflicting and present both equal as well as lower utilization of hospital care by non-native people $[9,10]$. Information about the use of other types of services is also heterogeneous. It is emphasized that the use of services is positively associated, among others, with age above 50 , legal status of stay $[11,12]$, being in possession of health insurance $[13,14]$, belonging to the older generation of migrants [15], higher income, social support, and lack of sense of discrimination [13].

The State healthcare system in Poland is funded through compulsory individual contributions to the National Health Fund (NHF) and through a government budget.

Address for correspondence: Dorota Cianciara, Department of Epidemiology and Health Promotion, School of Public Health, Centre of Postgraduate Medical Education, Warsaw, Kleczewska 61/63, 01-826 Warsaw, Poland

E-mail: dorotac@cmkp.edu.pl

Received: 05 April 2013; accepted: 25 April 2014
Foreigners who are entitled to health care under EEA rules on coordination of social security systems, during a temporary stay in Poland are entitled to receive free health care services, necessary on medical grounds, from health care providers who have concluded contracts with the NHF. The others should pay for voluntary health insurance in the NHF. Foreigners without work must produce proof of private health insurance in order to obtain their residence permit. Persons applying for refugee status do not need to have health insurance. Patients are admitted to a hospital which has a contract with the NHF, either through emergency care or through a referral by their doctor. Emergency care is available free for everyone, including those without state health insurance.

\section{OBJECTIVE}

The aim of the study was analysis of the cases of hospitalization of injured immigrants in 2008-2010 in Poland on the basis of data from General Hospital Morbidity Study. The analysis included: a) mode of admission of foreigners, b) length of stay, c) mode of discharge, d) seasonality of hospital admission, and e) spatial distribution of admissions.

\section{MATERIAL AND METHODS}

The General Hospital Morbidity Study (GHMS) has been conducted irregularly in Poland since the mid-1950's. Since 2000 , data on all hospitalization cases have been collected, 
with the exception of those treated in psychiatric hospitals or wards, and patients from hospitals for the uniformed services. The source of information in the GHMS is a statistical record created in the hospital. The research is a part of the national Public Statistic Research Programme.

Patients who were treated for injuries and poisoning (ICD$10=$ S00-T98), were selected from all the hospitalization cases. Cases of foreigners' hospitalizations are marked using a different code than in the cases of the Polish population, which allowed extraction of the group of foreigners. The following were analysed: a) mode of admission of foreigners i.e. referral, b) length of stay, c) mode of discharge, d) seasonality, and e) spatial distribution of hospital admissions.

\section{RESULTS}

Mode of admission. Planned admissions to hospital due to an injury constituted a minority of cases of hospitalization among both immigrants and general population (Tab. 1). The great majority of immigrants' hospitalizations were immediate admissions. Within the period of three years, the percentage of immediate admissions through selfreferral increased. In 2010, eight out of ten immigrants were admitted to hospital, omitting other forms of ambulatory and emergency care, while in the case of the general population only two out of ten patients were admitted in this way.

Table 1. Injury-related hospitalization among immigrants and general population by mode of admission (percentages of injury-related hospitalizations)

\begin{tabular}{|c|c|c|c|c|c|c|}
\hline \multirow{4}{*}{ Mode of admission } & \multicolumn{3}{|c|}{ Immigrants } & \multicolumn{3}{|c|}{ General population } \\
\hline & 2008 & 2009 & 2010 & 2008 & 2009 & 2010 \\
\hline & $\begin{array}{c}N= \\
4,661\end{array}$ & $\begin{array}{c}N= \\
21,234\end{array}$ & $\begin{array}{c}N= \\
19,837\end{array}$ & $\begin{array}{c}N= \\
540,044\end{array}$ & $\begin{array}{c}N= \\
669,258\end{array}$ & $\begin{array}{c}N= \\
732,997\end{array}$ \\
\hline & (\%) & (\%) & (\%) & (\%) & (\%) & (\%) \\
\hline Planned admission & 14.9 & 8.5 & 6.5 & 43.5 & 41.7 & 39.8 \\
\hline $\begin{array}{l}\text { Acute admission with } \\
\text { referral by emergency } \\
\text { care }\end{array}$ & 37.6 & 14.5 & 6.4 & 12.4 & 11.5 & 9.6 \\
\hline $\begin{array}{l}\text { Acute admission } \\
\text { with referral by other } \\
\text { facility }\end{array}$ & 26.6 & 7.7 & 6.2 & 25.1 & 25.8 & 26.7 \\
\hline $\begin{array}{l}\text { Immediate admission } \\
\text { (self-referral) }\end{array}$ & 20.4 & 69.3 & 80.9 & 18.8 & 20.9 & 21.2 \\
\hline Missing data & 0.5 & 0.0 & 0.0 & 0.2 & 0.1 & 2.7 \\
\hline Total & 100.0 & 100.0 & 100.0 & 100.0 & 100.0 & 100.0 \\
\hline
\end{tabular}

Length of stay. Within three years, the average length of stay in hospital due to injuries shortened, both among immigrants and the general population (Tab. 2). Length of stay of immigrants in hospitals was shorter than the length of stay among the general population. Female immigrants, similar to the general group of females hospitalized due to injury, usually stayed in hospital slightly longer than males.

Mode of discharge. In the analyzed period there were significant differences in the discharge mode of injured immigrants (Tab. 3). Between 2008-2009, the number of cases of discharges to home (after completion of therapeutic process) increased, while the number of discharges to outpatient care, discharges to in-patient care, and discharges
Table 2. Injury-related hospitalization among immigrants and general population by length of stay (days)

\begin{tabular}{cccccccccc}
\hline & \multicolumn{3}{c}{ Immigrants } & \multicolumn{3}{c}{ General population } \\
\cline { 2 - 10 } Year & \multicolumn{2}{c}{ Male } & \multicolumn{2}{c}{ Female } & \multicolumn{2}{c}{ Male } & \multicolumn{2}{c}{ Female } \\
\cline { 2 - 10 } & $\begin{array}{c}\text { Average } \\
\text { (days) }\end{array}$ & SD & $\begin{array}{c}\text { Average } \\
\text { (days) }\end{array}$ & SD & $\begin{array}{c}\text { Average } \\
\text { (days) }\end{array}$ & SD & $\begin{array}{c}\text { Average } \\
\text { (days) }\end{array}$ & SD \\
\hline 2008 & 3.7 & 7.9 & 3.9 & 6.6 & 6.1 & 9.2 & 7.0 & 9.6 \\
\hline 2009 & 1.5 & 5.0 & 1.8 & 5.0 & 5.9 & 9.0 & 6.8 & 9.4 \\
\hline 2010 & 1.0 & 4.2 & 0.9 & 3.7 & 3.2 & 6.9 & 3.7 & 7.3 \\
\hline
\end{tabular}

to long-term care decreased. The number of discharges at patient's own request and the number of deaths at the hospital also decreased. Some of these positive trends reversed in 2010, when, among others, the percentage of complete therapeutic processes decreased, while cases of discharge to out-patient care increased. A fairly constant tendency of maintaining a proportion of cases of discharges after completion of therapeutic processes and discharges to out-patient and inpatient care was reported among all the hospitalized patients of the general population.

Table 3. Injury-related hospitalization among immigrants and general population by mode of discharge (percentages of injury-related hospitalizations)

\begin{tabular}{|c|c|c|c|c|c|c|}
\hline \multirow{3}{*}{ Mode of discharge } & \multicolumn{3}{|c|}{ Immigrants } & \multicolumn{3}{|c|}{ General population } \\
\hline & 2008 & 2009 & 2010 & 2008 & 2009 & 2010 \\
\hline & $\begin{array}{c}N= \\
4,661\end{array}$ & $\begin{array}{c}N= \\
21,234\end{array}$ & $\begin{array}{c}N= \\
19,837\end{array}$ & $\begin{array}{c}N= \\
540,044\end{array}$ & $\begin{array}{c}N= \\
669,258\end{array}$ & $\begin{array}{c}N= \\
732,997\end{array}$ \\
\hline $\begin{array}{l}\text { Discharge to home } \\
\text { (completion of } \\
\text { therapeutic process) }\end{array}$ & 12.5 & 23.8 & 18.3 & 37.0 & 36.8 & 37.8 \\
\hline $\begin{array}{l}\text { Discharge to out- } \\
\text { patient care }\end{array}$ & 73.8 & 65.0 & 71.8 & 54.1 & 54.3 & 54.0 \\
\hline $\begin{array}{l}\text { Discharge to in- } \\
\text { patient care }\end{array}$ & 5.4 & 4.6 & 3.3 & 3.9 & 4.0 & 3.6 \\
\hline $\begin{array}{l}\text { Discharge to long- } \\
\text { term care }\end{array}$ & 0.4 & 0.3 & 1.1 & 0.4 & 0.4 & 0.4 \\
\hline $\begin{array}{l}\text { Discharge to other } \\
\text { forms of care }\end{array}$ & 2.3 & 3.5 & 3.2 & 1.6 & 1.5 & 1.3 \\
\hline $\begin{array}{l}\text { Discharge at own } \\
\text { request }\end{array}$ & 4.6 & 2.4 & 2.0 & 1.0 & 1.0 & 1.0 \\
\hline Death & 1.0 & 0.4 & 0.3 & 2.0 & 2.0 & 1.9 \\
\hline Total & 100.0 & 100.0 & 100.0 & 100.0 & 100.0 & 100.0 \\
\hline
\end{tabular}

Seasonality of admissions. Every year, the highest percentage of injured immigrants were admitted to hospital in August (Fig. 1), while the highest proportion of injured members of the general population were admitted in July (Fig. 2). Curves showing the month of admissions of patients from general population in different years present a similar and quite steady progress, while the curves showing the admissions of immigrants are varied and change dynamically. It should be noted that the last quarter of each year was the period of time when the number of admissions of native-population was significantly lower, in contrast to the higher number of immigrants' admissions.

Spatial distribution of admissions. Throughout the analyzed period, the highest proportion of injured immigrants was hospitalized in the Małopolskie Province, where from 24.9\% 


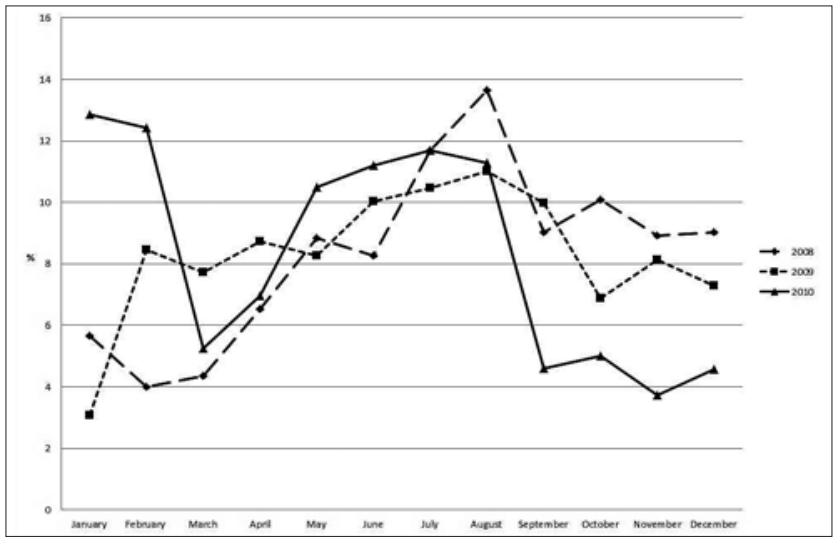

Figure 1. Month of hospital admissions of immigrants hospitalized because of injuries, Poland, 2008-2010 (percentages)

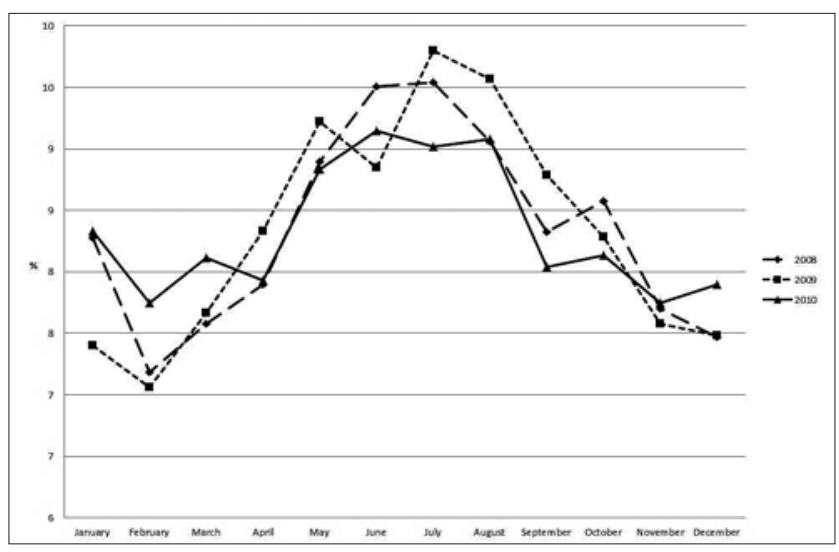

Figure 2. Month of hospital admissions of all patients hospitalized in Poland because of injuries 2008-2010 (percentages)

- 39.4\% of all admissions were reported. In 2010, $75 \%$ of all injured immigrants were treated the in hospitals of only two provinces: almost half in Mazowieckie Province and a third in Małopolskie Province (Tab. 4).

\section{DISCUSSION}

It should be noted that in the last year, about $95 \%$ of all injured immigrants' admissions were acute admissions, the majority of which $(80.9 \%)$ were through self-referral. Among the general population this percentage accounted for $21.2 \%$. High percentages of admissions of patients through emergency care have been observed for a long time in numerous medical problems and social contexts, not only among foreigners but also among the indigenous population [16]. However, the proportions revealed in the presented study suggest that for immigrants in Poland, in the event of injury, the most accessible form of aid is emergency care and self-referral. Presumably, this may be associated with the lack of health insurance, but this issue requires further research.

Dynamic changes were recorded in modes of discharge; however, it should be noted that the great majority of cases each year were eligible for further treatment as an outpatient. At the same time, there was a constant tendency for shortening the length of stay in hospital to one day in 2010. Both trends may indicate either that relatively minor injuries were treated, or the problems of affording costs for hospital services. An important factor may also be a change in the
Table 4. Injury-related hospitalization among immigrants by provinces (percentages)

\begin{tabular}{lrcc}
\hline Provinces & \multicolumn{3}{c}{ Year } \\
\cline { 2 - 4 } & 2008 & 2009 & 2010 \\
\hline Dolnośląskie & 0.6 & 5.5 & 8.2 \\
\hline Kujawsko-pomorskie & 1.5 & 0.4 & 0.5 \\
\hline Lubelskie & 10.0 & 1.7 & 1.8 \\
\hline Lubuskie & 2.3 & 0.5 & 0.4 \\
\hline Łódzkie & 3.8 & 2.0 & 0.3 \\
\hline Małopolskie & 24.9 & 39.4 & 30.9 \\
\hline Mazowieckie & 4.4 & 29.2 & 45.6 \\
\hline Opolskie & 2.5 & 0.4 & 0.4 \\
\hline Podkarpackie & 3.1 & 0.9 & 1.1 \\
\hline Podlaskie & 1.7 & 1.6 & 1.2 \\
\hline Pomorskie & 12.2 & 1.5 & 0.5 \\
\hline Śląskie & 5.5 & 0.7 & 0.6 \\
\hline Świętokrzyskie & 0.7 & 1.7 & 0.7 \\
\hline Warmińsko-mazurskie & 21.6 & 7.5 & 0.8 \\
\hline Wielkopolskie & 2.1 & 0.7 & 0.6 \\
\hline Zachodniopomorskie & 3.2 & 6.3 & 100.0 \\
\hline Total & 100.0 & &
\end{tabular}

national system of the contracting of medical procedures made in mid-2008 (DRG-based reimbursement).

Seasonal variation is a known feature of infectious diseases, numerous non-infectious diseases and injuries [17]. In the case of injuries, it is connected to both the seasonality of certain types of activities, as well as to sleep quantity in different seasons. The current study found that the hospital admissions of injured immigrants and members of general population show substantial seasonal differences. This suggests that the two groups differ in terms of the circumstances and mechanisms of injury, and the issue requires further thorough research.

Another issue which requires further research and analysis is that of the accumulation of immigrants' hospitalization in only two provinces with the capital cities Warsaw and Krakow. This may be due to the greater number of foreigners in these regions or a greater number of injuries among them, but another likely scenario is the utilization of health and hospital services. It is commonly noted that immigrants face many barriers while accessing health services $[18,19,20]$, similar to ethnic minorities and other non-privileged groups.

The utilization of health services is of great interest to the representatives of scholars of numerous medical and social fields. Associated with this is the use of other concepts, such as health seeking behaviour. In a comprehensive, not mechanical approach, the use of medical care is perceived as the result of interactions of numerous interlinked and interrelated factors. The socio-behavioural or Anderson's Model of Health Care Utilization is widely-used [21,22], which distinguishes three categories of factors which can influence individual and societal determinants of medical care. Predisposing factors include individual determinants, such as age, formal education, gender, religion, prior experiences with illness, and attitudes towards health services. Enabling factors are related mostly the with health system as well as network of social support. 
Need factors pertain to the perception of severity of illness or injury and self-care (e.g. home remedies). Among factors related to the health system, the so-called "four A's" may be taken into account, i.e. availability of services, which refers to the geographical distribution of facilities, accessibility in transportation terms, affordability of costs, as well as health insurance coverage, acceptability or appropriateness of the social interaction within health care. Due to the last factor, the organizational and cultural competence of staff should be taken into account, as well as physicians' religiosity, which is a major determinant of a good relationship with the patient [23].

The results obtained in the presented study should be considered as the effect of these complex determinants. More research is needed because of the noted differences in the utilization of hospital services by the injured immigrants and general population. Nevertheless, the results indicate that the health of immigrants, especially those who are not documented and lacking health insurance, require reconsideration of not only existing solutions, but also public health concern [24].

\section{CONCLUSIONS}

The findings bring to light issues not previously analysed in Poland. They present significant differences in the utilizations of hospital care by injured immigrants and the general population. These differences are probably related to the pattern of injuries and health outcomes. Problems with the accessibility to health care services are also of importance. Understanding the immigrant experience when accessing health care is essential for improving their health. Further research and the contribution of public health is needed.

\section{REFERENCES}

1. Salminen S. Are immigrants at increased risk of occupational injury? A literature review. The Ergonomics Open Journal. 2011; 4: 125-130. http:// www.benthamscience.com/open/toergj/articles/V004/125TOERGJ.pdf (access: 2013.02.21).

2. Salvatore MA, Baglio G, Cacciani L, Spagnolo A, Rosano A. WorkRelated Injuries Among Immigrant Workers in Italy. J Immigr Minor Health. 2013; 15(1): 182-187.

3. Consunji RJ, Jumangit A, Ameratunga S. A systematic review of road traffic injury risks for immigrant populations. Inj Prev. 2010; 16: A182 doi:10.1136/ip.2010.029215.650.

4. Hasselberg M, Laflamme L. Road traffic injuries among young car drivers by country of origin and socioeconomic position. Int J Public Health. 2008; 53(1): 40-45.

5. Kunst AE, Stronks K, Agyemang C. Non-communicable diseases. In: Rechel B, Mladovsky P, Devillé W, Rijks B, Petrova-Benedict R, McKee M. Migration and health in the European Union. WHO, European Observatory on Health Systems and Policies, 2011.p.114.
6. Nørredam M, Krasnik A. Migrants' access to health services. In: Rechel B, Mladovsky P, Devillé W, Rijks B, Petrova-Benedict R, McKee M. Migration and health in the European Union. WHO, European Observatory on Health Systems and Policies, 2011.p. 67-78.

7. Bonvicini L, Broccoli S, D’Angelo S, Candela S. Emergency room services utilization in the province of Reggio Emilia: a comparison between immigrants and Italians. Epidemiol Prev. 2011; 35(5-6): 259-266.

8. Nielsen SS, Hempler NF, Waldorff FB, Kreinre S, Krasnik A. Is there equity in use of healthcare services among immigrants, their descendents, and ethnic Danes? Scand J Public Health. 2012; 40: 260-270.

9. Cacciani L, Baglio G, Rossi L, Materia E, Marceca M, Geraci S, Spinelli A, Osborn J, Guasticchi G. Hospitalisation among immigrants in Italy. Emerging Themes in Epidemiology. 2006, 3: 4. doi:10.1186/17427622-3-4.

10. Carrière G, Paul A. Peters PA, Sanmartin C. Area-based methods to calculate hospitalization rates for the foreign-born population in Canada, 2005/2006. Health Reports 2012; 23(3) September 2012, Statistics Canada, Catalogue no. 82-003-XPE. http://www.statcan. gc.ca/pub/82-003-x/2012003/article/11693-eng.pdf (access: 2013.02.21).

11. Vargas Bustamante A, Fang H, Garza J, Carter-Pokras O, Wallace SP, Rizzo JA, Ortega AN. Variations in Healthcare Access and Utilization Among Mexican Immigrants: The Role of Documentation Status. J Immigr Minor Health. 2012; 14(1): 146-155.

12. Campbel RM, Klei AG, Hodges BD, Fisman D, Kitto S. A Comparison of Health Access Between Permanent Residents, Undocumented Immigrants and Refugee Claimants in Toronto, Canada. J Immigr Minor Health. 2012; doi:10.1007/s10903-012-9740-1.

13. Nandi A, Galea S, Lopez G, Nandi V, Strongarone S, Ompad DC. Access to and Use of Health Services Among Undocumented Mexican Immigrants in a US Urban Area Am J Public Health. 2008; 98(11): 2011-2020.

14. Ye J, Mack D, Fry-Johnson Y, Parker K. Health Care Access and Utilization Among US-Born and Foreign-Born Asian Americans. J Immigr Minor Health. 2012; 14(5): 731-737.

15. Su D, Wang D. Acculturation and Cross-Border Utilization of Health Services. J Immigr Minor Health. 2012; 14(4): 563-569.

16. Khaliq AA, Broyles RW. Hospital admissions: who is admitted through the emergency department? Health Serv Manage Res. 2006; 19(1): $13-22$.

17. Centers for Disease Control. Surveillance of Occupational Injuries Treated in Hospital Emergency Rooms - United States. Mortality and Morbidity Report Weekly, 1983: 32(7): 89-90.

18. Pithara C, Zembylas M, Theodorou M. Access and effective use of healthcare services by temporary migrants in Cyprus. Int J Migration Health Soc Care. 2012; 8(2): 72-85.

19. Sethi B. Newcomers Health in Brantford and the Counties of Brant, Haldimand and Norfolk: Perspectives of Newcomers and Service Providers. J Immigr Minor Health. 2012. doi:10.1007/s10903-0129675-6.

20. Gray BH, van Ginneken E. Health Care for Undocumented Migrants: European Approaches. Commonwealth Fund. 2012; 33.

21. Andersen R, Newman JF. Societal and individual determinants of medical care utilization in the United States. Milbank Mem Fund Q Health Soc. 1973; 51(1): 95-124.

22. Phillips KA, Morrison KR, Andersen R, Aday LA. Understanding the context of healthcare utilization: assessing environmental and providerrelated variables in the behavioral model of utilization. Health Serv Res. 1998; 33(3): 571-596.

23. Pawlikowski J, SakJJ, Marczewski K. Physicians' religiosity and attitudes towards patients. Ann Agric Environ Med. 2012; 19(3): 503-507.

24. Hospital Care Management. Uninsured patients require creative discharge plans. Hospital Care Management. 2012; 20(4): 49-54. 